\title{
THE ANTHRACITE-TIDEWATER CANALS
}

\author{
By Chester Lloyd Jones, Ph.D., \\ Instructor in Political Science, University of Pennsylvania, Philadelphia.
}

The coal-carrying canals were constructed during the period ${ }^{1}$ of great national interest in the opening of water routes to the West. Unlike the larger projects, they were intended to supply transportation to a special interest, and upon the development of that interest-the coal trade-depended their whole prosperity. Their construction took place at a time when public interest in waterways was at its height. Into the history of each enters much of the speculative element which attended the construction of all the early projects for furnishing cheap outlets for the undeveloped national resources. With the advent of the railroad as a transporter of coal their operation was found less and less profitable, and they have gradually dropped out of importance as industrial agents.

It is the object of this paper to review the history of these waterways and to summarize the conditions which determine whether or not they may again become available under the new economic conditions which have developed or seem likely to develop.

\section{The Delaware and Hudson Canal}

The construction of the Delaware and Hudson Canal was authorized by the joint action of the legislatures of Pennsylvania and New York in the sessions of 1822-3. The company became a banking concern and a large landholder-the latter through the desire to control tonnage for its waterway.

The period in which the project was launched was cne of great speculation in public improvements, and the stock was subscribed to the full amount by two o'clock of the first day on which the books were opened. The original plan had been for a canal and slackwater navigation, but an improvement, to consist of a canal alone, and finally of a canal and a railroad was substituted. The irst through shipments of coal took place early in 1829. The

1 The historical material used in this article is summanized from a monograph preface for the Carnegie Institution of Washington by the author.

$(\mathrm{\tau} \bigcirc 2)$ 


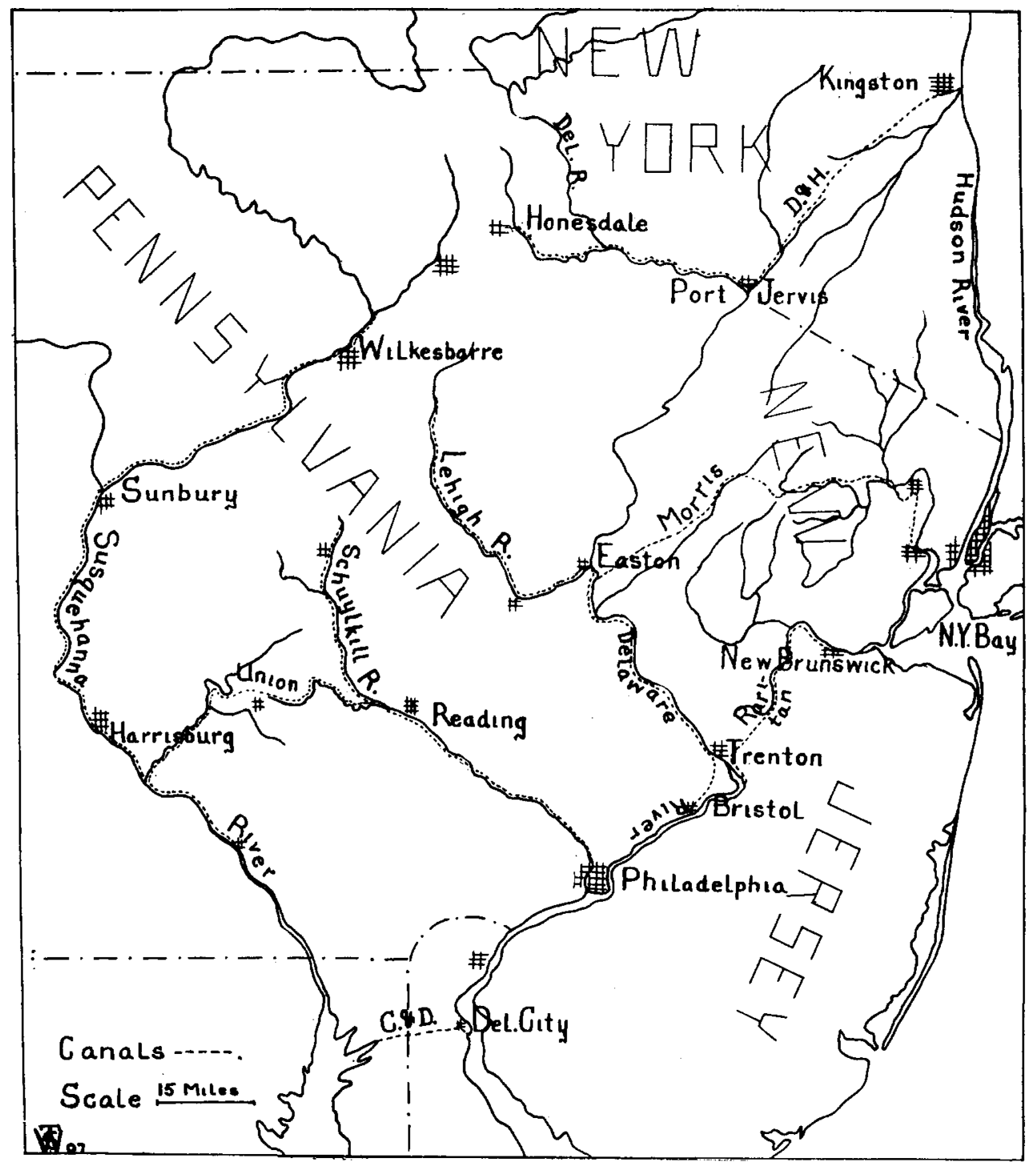

Map of Susquehanna and Anthracite-Tidewater Canals. 
coal was brought down to the canal from the mines at Carbondale at first by teams at a cost of from $\$ 2.25$ to $\$ 2.75$ per ton, later a substructure of timber faced "with rolled iron plates . . . . fastened . . . with screws" was used. The coal traffic on the canal in its early years received an important supplement from the general trade, which was a greater factor than on any of the other coal canals; but the income from it never equaled the running expenses of the waterway. The coal market was so limited that not until after the results of the panic of 1837 had disappeared was the company able to declare dividends. Then the trade necessitated the enlargement of the waterway-originally intended for thirtyton cargoes, and it was improved to accommodate forty and eighteentwentieths tons in 1844 , fifty tons in 1846 , ninety-eight tons in 1850 , I 40 tons in 1853 . Meanwhile the railroad to the head of navigation had undergone several improvements to increase its capacity. In I847 the first important contract was entered into to get the coal of other companies, thus greatly increasing both tonnage and tolls.

In the years following I 840 the company enjoyed a period of great prosperity. In 1843 all outstanding bonds were paid. By 1845 almost all the banking capital had been redeemed and the loans of credit by New York were canceled in I848 and I850. This left the company entirely free from debt. Soon after, however, the desire to expand to other markets led to the construction of railroads and to new bond isstues. The greatest railroad expansion comes, however, after I86I, and up to I865 the stockholders found their canal a rich source of income. How valuable a property it was may be judged by the following typical instances of dividends received: I 840 , I I per cent ; I847, 22 per cent; 1855 , I 8 per cent; I $858,5 \mathrm{I} / 2$ per cent (due to railroad expenditures) ; I860, 7 per cent ; I86I, 9 per cent; I862, I I I/2 per cent; I863, 34 per cent; I864, 3 I per cent, and 1867,16 per cent. The decrease after I864 was due to the transfer of much of the tonnage to railroad routes. The prosperity was due in large degree-in fact mainly-to the toll on coal of other companies. The first contracts for this service were made in 1849 , and soon furnished an important part of the income. By $\mathrm{I} 854$ the tolls paid by the Pennsylvania Coal Company, the chief independent company, for the year amounted to $\$ 54$ I,378.07.

An unfortunate dispute as to this traffic arose as to the tolls 
chargeable after the enlargement of the canal. The contest was taken before the courts in 1856 , and it dragged on until 1863 , when the court gave an award for the Delaware and Hudson Canal Company amounting to $\$ 350,000$. The legal victory was, in fact, a great economic misfortune. After the adverse decision the shipping of coal by the canal was cut off by the independent company, and its traffic turned to the Erie Railroad, which, in 1866 , carried almost all the coal formerly sent over the canal by the Pennsylvania Coal Company. The diversion of this traffic dealt a deathblow to the prosperity of the canal. In the two years 1865 and 1866 the company lost more than the entire amount of their claim for extra toll, and the canal income fell from about two and a half times the expenses for repair and maintenance to a little over one-fourth of their amount.

At once the policy of the canal company was changed. An attempt was made to greatly extend their railroad holdings, and thus to win back the traffic they had lost and to obtain access to new markets. In 1867 a railroad outlet through Scranton was secured by the absorption of the Union Coal Company. Another company, with coal lands and a railroad connection across the Susquehanna, was purchased, giving an outlet to Baltimore and to Jersey City. In 1868 a contract with the Erie was made to build a line to give access to the Rochester and Buffalo markets. Other branch roads were provided for, and an exchange of stock with the Erie brought about the identity of interests of those two companies. The Albany and Susquehanna Railroad was leased in perpetuity in 1869 , and further access to Baltimore acquired. Three years later the New York and Canada Railroad was put under construction to tap the Montreal market.

By the time of the panic of 1873 the company was in the full swing of the expansionist movement. Railroads had superseded the canal in the transportation interests of the company. How thorough had been this transformation in the five years since I867 is shown by the fact that by 1872 all statistics of canal traffic disappear from the reports and the only regular mention of the canal is in the entry of canal tolls in the income sheet.

The history of the canal since 1872 is an uneventful one of decline and abandonment. The coal shipments were practically confined to those made by the company and fell off yearly. In I897, 
preparatory to final abandonment, a part of the canal assets were charged off to profit and loss and subtracted from the surplus. The following year the "managers . . . decided . . . to cease operating the canal, . . . the cost of transportation is too great as compared with other methods." Since then the damages made by" freshets have not been repaired and "the cost of the canal . . . has been charged off and no longer stands as an asset."

\section{The Morris Canal Company}

Least successful of the coal carrying waterways was the Morris Canal-one which, even had railways not made competition by the route impracticable, would have had a hard time competing with the other water routes to the seaboard. The claims of the promoters of the enterprise were by contrast greater. They expected the Morris Canal to secure a monopoly of the trade of the west to New York, to control all the coal trade from the Lehigh region to tidewater and to develop along its route the greatest manufacturing district of the new world. The canal was first projected as a state work, but in 1824 was given to a private company. The physical difficulties to be surmounted were greater than in any of the other projects. The rise and fall to be overcome was reported as 1,730 feet, a forbidding distance, of which $I, 470$ feet must be overcome by inclined planes instead of locks.

The high tide of speculation at which the canal project was started brought offers of subscription of $\$ 20,000,000$ to the $\$ 1,000$,ooo of stock offered in the spring of I825. Public confidence soon fell away and by 1828 over one-third of the stock was forfeited through non-payment of assessments. The financial straits of the company were relieved by loans abroad, but the work dragged, and the first boat did not pass to Newark until the fall of 1831. Even after the canal was in working order it was difficult to borrow money to fit out boats for use thereon. Financial difficulties continued until the next period of speculation preceding the panic of 1837. Additions to stock authorized by the legislature in 1835 were eagerly subscribed for, the forfeited shares were easily sold at par, and in 1836 with this money the canal was completed to Jersey City. The directors boasted that in one year their financial operations had put the company in a position to discharge all debts "from their own capital and resources" and still have $\$ I, \infty \infty, 000$ 
for banking purposes. These finances, however, were largely concerned with "notes of other banks equal to specie," and when the panic of 1837 came it forced the company again into embarrassment.

A twenty-five ton canal, it was evident, was inadequate to maintain itself. Enlargement to a capacity of fifty-four tons was attempted, but while the improvement was still only under way the company was for ued into bankruptcy, and in 1844 was sold to satisfy a mortgage.

The purchasers reorganized the company by consolidating the old common stock and issting preferred upon which demands of ro per cent were guaranteed. The new company continued the improvements on the canal and the enlargement of the planes which, when they were acquired, passed boats only at one-fourth the speed of the lift locks. Up to this time no development such as had been hoped for in the through coal trade to tide had taken place. In I 847 even, only 17,885 tons reached Newark, and upon all through trade there was no profit. An enlargement to seventy-ton capacity was next attempted. By 1856 most of the planes on the west slope, where the chief lifting was to be done, had been enlarged and a depth of five feet of water attained. At last the tide seemed to have turned-the canal had been quadrupled in capacity and boats could be passed carrying sixty-five to seventy tons. Shipping facilities on the Delaware were improved and arrangements made to get coal from the Lehigh Valley Railroad as well as from the Lehigh Canal. Finally, in 1859 , the sale of the Delaware Division by the State of Pennsylvania to a private company made possible a combination as to toll rates which promised increased income.

The outlook for the Morris Canal at the outbreak of the Civil War was therefore more encouraging than at any other time during its history. The war period proved for it, as for other coalcarrying routes, a period of rich harvest. The total tonnage rose from 554,034 tons in 1858 to the highwater mark of 723,927 in 1864. More coal was offered than could be carried, though the boats were pressed to the limit of their capacity. The coal tonnage rose from 350.331 tons in 1859 to 459,175 tons in 1866 , an increase which, with the rise in tolls, brought dividends never before or afterward approached in the history of the company. The highest profits were reached in 1864 , when ro per cent was paid on both common and preferred stock. The period of prosperity was soon 
brought to an end. The railroads, heretofore the feeders of the canal, now became its competitors. This influence first began to be felt in 1866, when the Morris and Essex Railway began to supply with coal part of the territory formerly reached by the canal. To counteract the competition new enlargements were put under way and special inducements offered to boatmen to stay on the canal in the coal trade. But the rail rates, especially the rate wars, soon cut off all profits, and in 1870 the company asked the legislature for permission to lease the canal and its properties. Permission was granted. Early in $187 \mathrm{I}$ the Lehigh Valley Railroad leased the canal and its important terminal facilities in Jersey City for 999 years. The subsequent service rendered by the canal has been a decreasing one. Only in two years ( 1883 and 1884 ) after 1870 has the tonnage risen above 300,000 tons. By I 888 the trade had become "almost exclusively" local. The flood of 1902 on the Lehigh finally closed the western end of the canal, and it is now no longer open for use except for the local trade and for coal delivered to it by railroad.

By its original size and by the physical difficulties to be overcome the Morris Canal was from the first seriously handicapped as a route for the through trade. The part it played was consequently a disappointing one.

\section{The Delaware Division Canal}

The object of this detached portion of the state works of Pennsylvania, unlike that of the system which was to tap the trade of the west, was to supplement works already under way-the Lehigh improvements, with which interests it has now become merged. It was thus built with the definite thought that its value should be found in service to the coal traffic. The waterway was constructed in the years $1827-1830$, though navigation was still incomplete at the end of $183 \mathrm{I}$. Faulty construction, bad judgment in determining the size to be given the canal and the interstate jealousies of New Jersey and Pennsylvania hindered the usefulness of the waterway. New Jersey was reluctant to yield the use of the Delaware as a feeder, and Pennsylvania forced traffic through an artificial route to Bristol for fear an outlet lock to the Delaware and Raritan would divert the profits from her citizens to those of New Jersey. The dimensions of the canal locks were but half 
those of the Lehigh, and transshipment was thus necessary, or the use of small boats suitable to the Delaware. Recommendations that the canal be made uniform with the Lehigh remained unheeded by the legislature until railroad competition began to threaten both the New York and Philadelphia markets. Then improvements were put under way, but were not completed when the canal was sold with the other state works undisposed of, to the Sunbury and Erie Railroad in $\mathrm{r} 857$.

An independent company took over the canal the following summer and operated it for nine years. The improvement begun by the state was completed, but due to failure to come to amicable arrangements with the other waterways the canal did not share the phenomenal prosperity enjoyed elsewhere during the Civil War. The lack of harmony finally brought a proposal to buy the canal from the Lehigh Coal and Navigation Company, which was accepted by the Delaware Division Canal Company in $\mathrm{I} 866$.

\section{The Lehigh Coal and Navigation Company}

The plans to develop the mining lands on the Lehigh by means of a canal were developed earlier than the other projects already discussed. Indeed the Morris and Delaware canals were built largely as supplements to the Lehigh improvements.

Numerous unsuccessful ventures dating back as far as I793 prefaced the successful completion of a waterway down the Lehigh in I820. The coal was floated down in arks by means of artificial freshets. The tonnage grew rapidly, but was interfered with by the expense of constructing new arks for each trip, as they could not be returned up the river, but were broken up on arrival at Philadelphia. Since 1825 also an uninterrupted slackwater navigation had tapped the Schuylkill region. For these reasons an improvement of the waterway to a slackwater navigation up to Mauch Chunk was determined upon, especially as the state had committed itself to the improvement of the Delaware. The canal was able to accommodate boats of 120 tons by 1829 . Upon the completion of the Delaware Division the use of arks was gradually abandoned and permanent boats substituted. In the years following 1835 other slackwater improvements were introduced above Mauch Chunk and a railroad was substituted for the highest portion of the route.

The extensions were hardly completed when a disastrous flood 
almost wrecked the company in 1840 . A few years put it on its feet, however, and the period $1840-1867$ proved here, as on the Delaware and Hudson, one of exceptional prosperity, even the financial stringency of 1857 , though it caused grumbling, did not cut down the dividend-paying ability of the company.

The coal tonnage, which had risen from 365 tons in 1820 to 225,585 tons in 1840 , steadily grew to $1,276,367$ tons in 1855 . This was the period of the company's history during which its canal interests were most prominent in the minds of the managers. It was even planned to give up the mining of coal by leasing those properties and making the company a navigation company in a more confined sense. A change in this policy came with the year 1856 , when the Lehigh Valley Railroad paralleled the navigation, necessitating reduction in toll rates and involving a diminution in tonnage. As a result the managers report in 1859: "The company must look for their remuneration to the augmented production of the mines . . . from which to derive a revenue." The importance of railroad connections was also increased.

During the Civil War the necessity for turning to lines of activity other than the exploitation of the canal was not empirasized to the extent it would have been but for the great increase in demand for coal which, notwithstanding the railroad competition, gave the canal more traffic than it was prepared to handle. Consequently the war years show profits unapproached before that time, though freshets, strikes and rate wars, and in 1862 a disastrous flood, cut down the profits that might have been reaped.

The Lehigh Company was not ignorant of the fact that the railway development in progress threatened its prosperity, and even in these years of exceptional dividends took steps to counteract the coming disadvantages under which it would have to work. Extensive coal lands were purchased, the smaller tributary railways absorbed and an extension of the Lehigh and Susquehanna Railway-till now a feeder to the canal only-was made from Mauch Chunk to Easton to compete with the Lehigh Valley Railroad. The company entered into the strife for tonnage and markets that absorbed the interest of the coal transportating routes in $1860-$ 70. As a part of this policy the Delaware Division Canal was acquired in 1866 . In making these extensions the corporation outran its credit, and in 1870 found itself facing the possibility of 
a combination of the railroads across New Jersey, which would leave it without a rail outlet to New York. Both financial and strategic reasons counseled that an alliance be made with the Central Railroad of New Jersey, the only independent outlet remaining. For these reasons the railroad properties were leased to the Central Railroad of New Jersey in March, I87I, for a rental of one-third of the gross receipts on the line. For the time the Lehigh Company again became "a coal and navigation company . . . as during the period of (their) greatest prosperity." It had thus gotten rid of part of its financial responsibility before the panic of 1873 . When that came the company was further embarrassed and was forced to sell its Wyoming coal holdings to a company allied- with the Central Railroad, which latter corporation also leased all other properties of the Lehigh Company, including its two canals, in December I873. This agreement removed the Lehigh Company from active business operations until I877, when the Central Railroad went into the hands of a receiver, and the leased properties, with the exception of the railroad, were returned to the owners. The return was by no means a misfortune, for the lessees had expended over $\$ \mathbf{I}, \mathbf{I}$ OO,O0O in improvements upon the property which now returned to the owners without cost to them.

The relative importance of the company's properties had now changed radically. The majority of the capital was in the railroad -the rent from which formed the chief item of income. Next in value were the mines, and last, the canal. The canal tonnage since this period has gradually fallen with the increase of railroad connections to New York, the lowering of rates and the unfavorable terms granted on certain routes-notably the Delaware and Raritan Canal-making through trade in competition with the railroads unprofitable.

The success of operations is shown by the course of profits. From the time when the company again assumed control in 1877 up to I884 the yield varied, showing a gradual increase up to $\$ 276,106.20$ in the latter year. After that profits gradually decreased to 1893 , when they reached $\$ 16,986.77$. Since then there have been small profits and small losses on operation. A disastrous flood in 1902 necessitated increased repairs, and by cutting off tonnage helped to bring deficits.

At present the canal is operated with a tonnage of 240,151 tons (I906). 


\section{The Schuylkill Canal}

The Schuylkill Canal is an intermediate term between the distinctively coal-carrying routes and the canals to tap the trade of the West. Originally planned with the latter object in view, its traffic was almost from the first chiefly coal. The construction for boats of twenty-five tons, with a depth of three feet, took place in the years I8I8-25. In I832, to accommodate the growing coal trade, it was enlarged to eighty tons capacity, and in $1845-47$ to I70 tons. Even in the latter year, however, the coal traffic was only 6,500 tons. Beginning with 1832 the canal had a practical monopoly on the coal trade from the district it served, and for the next few years showed handsome profits. The stock rose to three and one-half times its par value, a figure till then unprecedented in the history of American joint-stock companies. The end of the prosperity of the route was foreshadowed in 1842 , when the Philadelphia and Reading Railway was completed from the Falls of the Schuylkill to Port Richmond. This, with the other connections, gave a through rail route to the coal mines. The enlargement above mentioned and serious floods brought financial embarrassment, necessitating a reorganization of the company in 1852 . In $186 \mathrm{I}$ the Reading Railroad began to work for the monopoly of the trade by buying up the branch coal roads. The canal company adopted similar tactics and secured favorable tonnage contracts for ten years, and satisfactory dividends were again resumed in 1866-67. The independent existence of the canal company was brought to an end in 1870 by the continuance of the Reading's plan to capture the avenues of coal supply from the Schuylkill region to Philadelphia. The canal and its properties in this year were leased to the Reading for 999 years, at a yearly rental of $\$ 655,000$. Since that time no important expenditures have been made to improve the canal, and through traffic has practically ceased.

\section{Historical Review Summarized}

In all of the waterways, the history of which has been reviewed, the main trade has been coal. The general trade has been negligible from the standpoint of profits, with the exception, perhaps, of the trade in iron ore on the Lehigh and Morris Canals.

The canals fall into two classes-the Morris and the Delaware 
and Hudson; and the Lehigh, the Schuylkill, and the Delaware Division. The first group involved carrying all through freight over heights of land intervening between the ends of the waterways. The latter group takes the heavy freight offered downward only. These groupings also correspond to the availability of the canals as trade rontes, in the past and in the future. From this point of view the situation of the Morris Canal is the least favorable. The physical difficulties to be overcome place it at a permanent disadvantage in comparison with the other routes, notwithstanding the location on the line from the coal fields to New York. In the present state of mechanical development the extended use of the inclined plane, even if the water supply could be increased sufficiently to support an enlarged canal, seems to be out of the question.

The Delaware and Hudson, except that inclined planes are not necessary, labors under similar disadvantages, but its ability to handle a large traffic is proved by its history. Its operation has been found unprofitable under present conditions, however, and the railroad interests in control do not look upon its rehabilitation as a practical matter. This is also the case with the Schuylkill route, though in this case there is no summit level to be overcome.

The Lehigh and Delaware Division Canals, now under one ownership, are in a different class. The physical conditions are more favorable and it is also to be noted that unlike the other two they are held by a company in which the development of the canals would not merely mean a supplemental outlet to a market already reached by its railroad holdings, but an independent access to markets now reached through agencies furnished by other transportation companies. These canals also have proved in the past their ability to handle traffic.

\section{The Present Problem of Coal Canal Transportation.}

The problem of successful maintenance of a coal-carrying canal is the same as for other transportation routes-the securing of tonnage. This is difficult at present because of the high local rates charged on the railways which might prove feeders to the waterways. As a result the canals find it difficult to make a competitive rate such that they can compete with rail carriage on the through trade. The high local rates on coal shipped to the canals 
form so large a part of the cost of carriage to market that the canals must work at a peculiar disadvantage, unless they can supply the tonnage, directly from their own coal mines or over railroads under their control. When the competing railroad companies are also coal mine owners, it is evidently against their interests to establish local rates which would divert traffic from their own to the rival transportation interests of the canals.

Another disadvantage of canals is the necessity of transshipment, especially when the cargoes on the canals are of small size. Where the coal must be loaded from a railroad to a canal boat, and later from a canal boat again to a railroad car, the incident expense greatly cuts into the ability of the canal to compete. Where the second transshipment can take place into large barges, the disadvantage is not so great, especially as the canal boat will have the ability to come directly along side, and wharfage charges can be avoided.

The inability to market products during the winter is a permanent limitation on the use of canals. Where the business must for months be transferred to the railroads there can naturally not be the continuity of business relations that is so much to be desired.

The technical problem of reducing the fixed charges of canal maintenance and the delays of lockage is also important in determining whether the canals can again be made available. The fixed charges of attendance of lockmen and the repairs of locks form the largest single item of expense on an average canal of roo tons to I5O tons capacity. This renders the decrease of the number of locks an important factor in cutting down cost of operation. Modern engineering is making possible the use of locks of much greater height than those how in place on canals of medium size, and if such could be introduced with profit, adopting a sixteen- or twenty-foot lift where now eight- or ten-foot locks are in use, an important saving could be made.

Locks of higher lift would also mean a great economy in time, for it takes only a small increase of time to fill or empty a lock of twice the usual present height. The great waste of time in lockage at present is consumed in getting the boat into the lock, not in raising or lowering the boat. The loss occasioned in checking a boat which is going into the lock too rapidly, or in starting one lacking momentum, and pulling it into the lock by hand or by 
winches consumes many times the time necessary to do the actual work of lockage. Where short lift locks are used the time spent in lockage is often as great as the entire time spent in actually traversing the prism. Higher locks would therefore mean a decrease in the personnel and equipment necessary to operate the canal as well as increased earnings on the capital invested in boats, due to increased ability of each boat to take produce to market.

The most decided advantage of a canal is in the low cost of moving freight. Where speed is not an essential, as in the heavy and rough products, this may prove quite sufficient of itself to overcome disadvantages which would otherwise make operation unprofitable. The actual cost of moving freight-exclusive of lockage-on a Ioo-ton barge canal is somewhat less than one-half cent per ton per mile. If the barge is increased in size, the cost per ton mile is more than proportionately less.

Where the fixed charges of a canal are low, this advantage in towing cost becomes a very important feature. A canal whose fixed charges and towing expenses with barges of Ioo-tons capacity, on a freight total of 250,000 tons, give a ton mile cost of one and one-half cents, would give a ton-mile cost of one cent per ton-mile on 500,000 tons and three-quarters of a cent per ton-mile on $\mathrm{I}, 000,000$ tons. Increase in the size of the barges, decrease in the number of locks, or in the cost of towage, would, of course, further decrease ton-mile cost. In the latter item experience with electric traction in Europe shows that there important savings can be made over animal power. Towing from the bank of canals of the character under discussion has proven less wasteful of power than towing by tugs. Further, the distinct advantage is gained that it is accompanied by less washing of the banks. These reasons also set the profitable limit of speed even when mechanical traction is introduced at four miles an hour.

\section{Can Coal be Profitably Carried by the Canals under Present} Economic Conditions?

The Morris Canal seems to be handicapped to such a degree that its abandonment may be accepted as final. Under present conditions the operation of the Delaware-Hudson route, once an important avenue of trade, has been found unprofitable, as already indicated, and there is no prospect of its further use in the near future. The same is true of the Schuylkill Canal. 
Of the distinctively coal canals discussed, the only one in operation throughout its whole length is that furnishing an outlet by the Lehigh-Delaware route. This canal still carries a coal traffic of over 200,000 tons. During the past summer experiments have been introduced on the upper section with the object of finding whether mechanical traction can be introduced at a profit. Two experimental sections of two miles each have been installed. One section is operated by an electric device of the American Adhesion Traction Company; the other by a modification of the Lehigh Company's electric mine locomotive. All the traffic on both of these sections is handled exclusively by these machines, which run along the line of the old towpaths. They handle the traffic fairly well, and the expense of operation is less than that of animal power. Whether the fixed charges on the investment will overbalance this advantage cannot be stated as yet because of the short time in which the experiment has been in operation. Whether the canal can again prove itself able to furnish a profitable outlet for the coal trade depends upon the success of experiments of this nature and modifications to cut down the fixed charges, such as are mentioned above.

\section{The Relation of the Canal to the Coastwise Inland Waterways}

If the canal can again prove itself able to deliver coal at the Bristol wharves on terms equal to the rates offered by the railroads, it would seem to have an assured business, even under present conditions, for the following reasons:

(I) To the Philadelphia market-the one to which the canal first sent its traffic-the canal has immediate access. The size of the city makes the market to be supplied one capable of large development.

(2) If the coal can be brought economically to Philadelphia, even under present conditions an important trade southbound can be developed. This would necessitate transshipment to larger coal barges, but that charge could be borne without destroying profits. That this is the case is proven by the fact that the Reading Railroad finds it profitable to transship coal at Port Richmond from its cars to coal barges which it sends through the Chesapeake and Delaware Canal to the Baltimore, Washington and Norfolk markets. A profitable business has thus been built up in spite of the canal tolls involved on the Chesapeake and Delaware 
Canal. If the Lehigh Canal could profitably bring coal to Bristol, this trade would be open to it also.

The possibilities of developing markets other than Philadelphia would be greatly increased should the present movement to improve the coastwise waterways be attended with success. The trade to the south would be on a better footing because of the increased capacity of the boats into which the transshipment could be made, and because of the abolition of canal tolls.

More important even than this would be the outlet again opened to the canal, through the Delaware and Raritan, to the New York market. This would be a revival of a trade which for years formed an important factor in the total business of the Lehigh and Delaware canals. In $1867,472,75 \mathrm{I}$ tons of coal from the Lehigh region passed into the navigable feeder of the Delaware and Raritan. By the same route were sent, even as late as 1884,238 ,756 tons. This trade represented in each of these years nearly twice the amount that reached Bristol for the Philadelphia trade.

At present the Pennsylvania Railroad interests controlling the Delaware and Raritan route maintain the charges at such a figure that no competition can be given to the railroads by the canal company on through coal trade to New York. Were the tolls abolished and the chanel widened this market, like that to the south, would be open to exploitation by those delivering coal by water.

The answer to the question of the future availability of the coal canals is therefore a double one. In the case of the Morris Canal its future availability seems highly improbable. In the case of two, and perhaps the four others, the problem is a technical onewhether the improvements of modern engineering can make their operation so economical as to make their use as a supplement to the railroads in carrying low-class freight a profitable one. Physical ability to handle traffic is proved by their history. Availability of tonnage, through the granting of competitive rates on the feeding lines, and economy of operation, are problems to be determined by the community of railroad and canal interests and by improvements in engineering. A revival in the near future seems possible on but two of the waterways-the ones carrying coal on the LehighDelaware route. 